\title{
РЕЦЕНЗІЯ \\ НА МОНОГРАФІЮ ПАЙДИ ЮРІЯ ЮРІЙОВИЧА «ПРАВА ЛЮДИНИ ТА РЕЛІГІЙНА СВОБОДА: СОЦІОКУЛЬТУРНІ ІМПЛІКАЦІї ТА НОРМАТИВНА ПРОПОРЦІЙНІСТЬ ${ }^{1}$
}

Цимбалюк М. М.

Досвід багатьох країн світу переконливо свідчить про те, що запорукою процвітання будь-якої нації $\epsilon$ іï здорова духовна сфера. Адже саме висока моральність, чуттєвість, домінуюча роль у якій належить релігії, формує людину. У системі українських і зарубіжних наукових розвідок питанням віровчення завжди приділялася значна увага. I це не випадково, адже від рівня релігійного світогляду, від ефективності застосування його методологічного потенціалу залежить розвиток інших сфер життєдіяльності суспільства, а отже, і держави загалом.

Одним із найбільш складних і водночас актуальних моментів функціонування правової системи суспільства $\epsilon$ питання співвідношення релігії та права. Це пояснюється як багатогранністю природи цих явищ, так і не завжди коректним розумінням еволюції самої системи правового регулювання. Останнє, як правило, зумовлене поширеною думкою про те, що в умовах західної цивілізації домінантою розвитку взаємодії права й релігії $є$ лінійний рух секуляризації права, його максимальне відмежування від релігії. Розгляд цих проблем становить також суто науковий інтерес, оскільки в умовах методологічної плюралізації сучасної юриспруденції постало завдання з перегляду основних питань співвідношення права та релігії, що реалізовується за допомогою виходу у світ численних монографій, підручників, навчальних посібників, а також захисту кандидатських і докторських дисертацій. Досить вагомою виявилася проблема оптимального поєднання сучасного, новітнього філософсько-світоглядного та державно-правового матеріалу з традиційними, класичними розробками у сфері релігієзнавства, державознавства й правознавства. Не менш важливою та актуальною виявилася проблема переосмислення й одночасної переоцінки низки морально застарілих державно-правових поглядів, політико-правових орієнтацій і релігійно-духовних цінностей.

Зокрема, необхідно відкоригувати усталене у свідомості фахівців у галузі юриспруденції, політології, філософії, соціології та інших суспільних наук уявлення про релігію та право, суспільство й державу, політику та демократію як про виключно станові явища й інституції, адже вони містять також національні, групові, кланові, етнічні, особистісні та багато інших ціннісних установок та інтересів.

У цьому контексті надзвичайно гострою $\epsilon$ потреба в удосконаленні юридичної науки, а саме в розро-

1 Пайда Ю. Ю. Права людини і релігійна свобода в умовах діалогового характеру правової культури : монографія. Харків : ХНУВС, 2018. 364 с. бленні цілісних доктринальних підходів до розуміння та пояснення проблем релігійної свободи в контексті загальних прав людини. Тому з огляду на складність, багатоаспектність, а інколи й суперечливість старих і нових державно-правових явищ та інституцій цілком виправданим та логічним $\epsilon$ виведення нової концепції філософського осмислення необхідності й доцільності, меж і підстав релігійної свободи людини як соціальної особи та громадянина держави.

Монографія, яку пропонує науковій громадськості Пайда Юрій Юрійович, виявилася на часі. Адже ця робота підготовлена з урахуванням новітніх концепцій українського державотворення та правотворення з використанням сучасних розробок відомих вітчизняних і зарубіжних учених - правників, політологів, істориків, релігієзнавців, культурологів, соціологів, психологів та інших.

У першому розділі автор цілком слушно резюмує, що дослідження прав людини та релігійної свободи $є$ вкрай важливим, оскільки релігія впродовж усієї історії людства залишається важливим елементом життєдіяльності людських спільнот. Релігійну свободу та релігійні права відносять до найвагоміших чинників, які впливають на відносини між такими суспільними інститутами, як держава й церква. При цьому варто погодитися з дослідником у тому, що понятійно-теоретичні особливості сучасних релігійних інституцій свідчать про наявність різноманітних інституціоналізованих форм, притаманних усім світовим релігіям.

Розкриваючи історико-теоретичні та філософсько-правові аспекти права на свободу світогляду й віросповідання в Україні, науковець аналізує ретроспективу становлення та розвитку цієї галузі права. Він зауважує, що морально-ціннісна зумовленість правового регулювання свободи світогляду та віросповідання базується на необхідності створення й забезпечення правових гарантій щодо задоволення морально-ціннісних потреб особи, реалізації їі права на вільне провадження релігійних культів і задоволення духовних потреб.

Цікавим є спостереження Ю.Ю. Пайди щодо того, що релігійні норми, якщо порівнювати їх із нормативноправовими актами, нормативно-правовими договорами та іншими джерелами права, втратили суттєве значення для системи джерел права й регулювання суспільних відносин, натомість забезпечують регулювання тільки внутрішніх церковних справ та інших релігійних відносин. Для українського суспільства, яке намага- 
ється реанімувати свої духовні першоджерела, дуже важливо зрозуміти це та, відповідно, адаптувати норми релігії до інших суспільних норм, насамперед державного права та законодавства.

Розуміючи, що релігійна свобода $є$ одним із фундаментальних міжнародних гуманітарних стандартів у сфері забезпечення прав людини, дослідник пропонує шляхи подолання проблем подальшого вдосконалення вітчизняного законодавства щодо дотримання релігійної свободи в Україні, що залишається в центрі уваги правників, релігійних і громадських діячів, політиків, соціологів та навіть психологів. Сучасна ситуація в нашій державі вимагає постійного звернення до досвіду дотримання міжнародних гуманітарних стандартів захисту релігійної свободи, що забезпечить постійний дієвий міжконфесійний діалог.

Вивчаючи актуальні питання вдосконалення нормативно-правового регулювання прав людини та релігійної свободи, Ю.Ю. Пайда абсолютно виправдано наголошує на доцільності імплементації міжнародно-правових норм у цій сфері на рівні національного законодавства. Шлях України до узгодження ії законодавства з міжнародними гуманітарними стандартами, зокрема стосовно свободи думки, віросповідання й релігії, безпосередньо залежить від ратифікації міжнародно-правових актів, поширення судової практики застосування норм прецедентного права, контролю в повсякденному житті суспільства за додержанням основних прав і свобод людини, проведення відповідних загальнодержавних заходів просвітницького характеру.

Тому запропоноване видання загалом $\epsilon$ однаково важливим і для тих, хто лише починає свій шлях у науку, i для тих, хто вже має вагомі здобутки в ній, і навіть для тих, хто зовсім не цікавиться питаннями науки, а просто має потребу у всебічній самореалізації, адже свобода вибору - одна з основоположних свобод та водночас найскладніша позачасова проблема людини як розумної соціалізованої істоти.

3 огляду на вищенаведене вважаю, що монографія Пайди Юрія Юрійовича «Права людини та релігійна свобода: соціокультурні імплікації та нормативна пропорційність» відповідає всім вимогам, які висуваються до такого типу видань, що дає підстави рекомендувати рукопис до популяризації через друк і тиражування та надалі до використання в освітньому процесі, для подальших наукових пошуків і розроблення механізмів урегулювання релігійних відносин у сучасному українському суспільстві.

Цимбалюк М. М., доктор юридичних наук, професор, заслужений юрист України, академік Академії наук вищої освіти 